\title{
Effect of neem extract on the cotton aphid
}

\author{
Terezinha Monteiro dos Santos ${ }^{(1)}$, Nivânia Pereira Costa ${ }^{(2)}$, Adalci Leite Torres ${ }^{(3)}$ and Arlindo Leal Boiça Júnior ${ }^{(3)}$
}

(1) Universidade Federal de Lavras, Dep. de Entomologia, Caixa Postal 3037, CEP 37200-000 Lavras, MG. E-mail: tmonteirodosantos@yahoo.com.br (2)Universidade Federal da Paraíba, Centro de Ciências Agrárias, Campus II, CEP 58397-000 Areia, PB. E-mail: npcosta@cca.ufpb.br (3)Universidade Estadual Paulista, Fac. de Ciências Agrárias e Veterinárias, Dep. de Fitossanidade, Via de Acesso Prof. Paulo Donato Castellane, s/no, CEP 14884-900 Jaboticabal, SP. E-mail: adalci@ibest.com.br, aboicajr@fcav.unesp.br

\begin{abstract}
The aphid Aphis gossypii Glover (Hemiptera: Aphididae), a harmful pest on cotton, causes direct damage, reducing plant vigor, and indirect damage by honeydew secretion and transmission of several viruses. Due to the problem of pesticide resistance, alternative techniques for chemical control, such as the use of natural insecticides, have been object of research. The effects of aqueous extracts of neem (Azadirachta indica A. Juss) seed powder on the development, survival and fecundity of A. gossypii were evaluated. Treatments consisted of neem seed powder in the concentrations of $23.8,122.0,410.0$ and $1,410.0 \mathrm{mg} / 100 \mathrm{~mL}$ of distilled water. Mortality rate during the nymphal development for aphids maintained on cotton leaf discs treated with the two highest concentrations were, respectively, $60.0 \%$ and $100.0 \%$. With the exception of the highest concentration $(1,410.0 \mathrm{mg} / 100 \mathrm{~mL})$, neem concentrations did not extend the aphids' development period. The net reproductive rate $\left(\mathrm{R}_{0}\right)$ was of 35.0 nymphs/female for control aphids and of $0.0 \mathrm{nymph} / \mathrm{female}$ when the group of females was exposed to neem seed powder at $1,410.0 \mathrm{mg} / 100 \mathrm{~mL}$ since birth. The aqueous extract of neem seeds is efficient against the aphid $A$. gossypii, causing nymph mortality and reducing their survival period and fecundity.
\end{abstract}

Index terms: Insecta, Aphis gossypii, Azadirachta indica, Gossypium hirsutum, aqueous extract.

\section{Efeito de extrato de nim sobre o pulgão-do-algodoeiro}

\begin{abstract}
Resumo - O pulgão Aphis gossypii Glover (Hemiptera: Aphididae), praga prejudicial à cultura do algodoeiro, causa danos diretos, reduzindo o vigor da planta, e indiretos, ao secretar substância doce e transmitir viroses. Em virtude da resistência desse afídeo aos inseticidas, técnicas alternativas ao controle químico, como o uso de inseticidas naturais, têm sido pesquisadas. O objetivo deste trabalho foi avaliar os efeitos de extratos aquosos de pó de amêndoas de nim (Azadirachta indica A. Juss) sobre o desenvolvimento, sobrevivência e fecundidade de A. gossypii. Os tratamentos consistiram de pó de amêndoas de nim nas concentrações de 23,8, 122,0, 410,0 e $1.410,0 \mathrm{mg} / 100 \mathrm{~mL}$ de água. Os porcentuais de mortalidade durante o período ninfal para os pulgões mantidos sobre discos foliares de algodoeiro imersos nas duas maiores concentrações, foram, respectivamente, $60,0 \% \mathrm{e}$ $100,0 \%$. Com exceção da maior concentração $(1.410,0 \mathrm{mg} / 100 \mathrm{~mL})$, as demais não prolongaram as fases de desenvolvimento dos pulgões. A taxa líquida de reprodução foi de 35,0 ninfas/fêmea na testemunha e de 0,0 ninfa/fêmea no grupo dos pulgões expostos à concentração de $1.400 \mathrm{mg} / 100 \mathrm{~mL}$, desde o nascimento. $\mathrm{O}$ extrato aquoso das sementes de nim é uma alternativa eficiente para o controle de A. gossypii, causando mortalidade de ninfas e reduzindo os períodos de sobrevivência e fecundidade.
\end{abstract}

Termos para indexação: Insecta, Aphis gossypii, Azadirachta indica, Gossypium hirsutum, extrato aquoso.

\section{Introduction}

The aphid, Aphis gossypii Glover (Hemiptera: Aphididae), is one of the most common species in cotton (Heneberry \& Jech, 2001), and is usually found on the abaxial surface of leaves, feeding on the phloem (Freeman \& Smith, 2002). As a result of feeding, plant yield is reduced. The secretion of honeydew contaminates plants, allowing associated fungi to grow and causing, in addition, more than 50 types of diseases in plants, due to the transmission of viruses (Heneberry \& Jech, 2001).
One of the first approaches utilized by growers to protect cotton plants from the aphid A. gossypii and from other pests is the use of insecticides. As such applications are quite frequent, most natural enemies are eliminated when the aphids are still capable of developing resistance to those products (Godfrey et al., 2000), making subsequent treatments inefficient and leading to an increase in aphid population levels (Godfrey \& Fuson, 2001). Alternative techniques for chemically controlling of cotton aphids are the biological control and the use of natural insecticides and resistant plants (Weathersbee 
III et al., 1995; Kabissa et al., 1996; Chitra et al., 1997; Mann et al., 2001).

Azadirachtin, a chemical complex found in seeds of neem, Azadirachta indica A. Juss, is the main component responsible for the toxic, repellent, antifeedant, growth-inhibiting, oviposition-inhibiting and sterilizing effects in insects (Ahmed \& Grainge, 1986; Schmutterer, 1990; Mordue \& Nisbet, 2000; Martinez, 2002). More than 400 insect species belonging to the orders Diptera, Hymenoptera, Coleoptera, Lepidoptera, Orthoptera and Hemiptera are susceptible to neem effects (Martinez, 2002). The extract of this plant reduces the population of several aphid species in many crops, causing high mortality and decreasing fecundity, as well as inhibiting population growth (Lowery et al., 1993; Stark \& Rangus, 1994; Partridge \& Borden, 1997; Ulrichs et al., 2001; Tang et al., 2002).

Neem extracts are usually safe for beneficial organisms, such as bees, predators and parasitoids, mammals, and for the environment (Ahmed \& Grainge, 1986; Tang et al., 2002). This plant is an interesting option for integrated pest management programs, since it is selective, presents a less negative impact on the ecosystems and works in association with biological control organisms (Stark \& Rangus, 1994; Immaraju, 1998; Tang et al., 2002).

The objective of this work was to evaluate the effects of aqueous extracts of neem seeds on the development, survival and fecundity of $A$. gossypii on cotton.

\section{Material and Methods}

This work was carried out from August to October 2002. A. gossypii rearing was started with aphids collected from a cotton field located at Universidade Estadual Paulista, Faculdade de Ciências Agrárias e Veterinárias, Campus Jaboticabal, SP, Brazil. The aphids were then transferred to cotton plants of cultivar IAC 22 maintained in $500 \mathrm{~mL}$ plastic cups, containing a mixture of three parts soil, one part sand and one part manure and 0.5 part vermiculite as substrate. Every 15 days the aphids were transferred to new plants, at a plant age of 20 days after emergence. The rearing was maintained in a greenhouse lined with anti-aphid netting, to avoid infestation by other aphid species and by natural enemies.

The wingless $A$. gossypii females were selected at random, transferred to cotton leaf discs of $5.0 \mathrm{~cm}$ in diameter and maintained on $1 \%$ agar in Petri dishes.
Neonate nymphs were obtained after 24 hours and then these nymphs were used in the experiments.

In order to evaluate the effect of azadirachtin on A. gossypii, the extracts were prepared beforehand, 16 hours prior to the experiment start. The treatments consisted of neem seed powder at concentrations of $23.8,122.0,410.0$ and $1,410.0 \mathrm{mg} / 100 \mathrm{~mL}$ water and control consisted of distilled water. Discs measuring $5 \mathrm{~cm}$ in diameter were cut out from the center of cotton leaves, cultivar Coodetec, from field-grown plants. Each leaf disc was dipped into aqueous extract of neem seed powder for 30 seconds and then air dried.

Leaf discs corresponding to each treatment were individualized and maintained with their abaxial surface facing up on a $1.0 \mathrm{~cm}$ layer of agar $1 \%$ in a Petri dish with $12 \mathrm{~cm}$ in diameter. Neonate nymphs were individualized on the surface of each leaf disc with the use of a number zero soft hair brush. Each Petri dish was sealed with voile fabric, kept in place by rubber bands and maintained in incubator at $25 \pm 1{ }^{\circ} \mathrm{C}$, with a 12-hour photophase and relative humidity of $70 \pm 10 \%$. Every four days the dishes containing leaf discs and agar were changed and the new leaf discs were not submitted to the neem treatments. During the reproductive period, the neonate nymphs were daily counted and then removed. A completely randomized design was utilized, with 60 replicates per treatment. Each experimental unit consisted of a Petri dish containing a layer of agar and the aphid. Data were submitted to analysis of variance and means were compared by Tukey test at $5 \%$ of probability.

Daily observations were made on the number of molts undergone by the aphids, including those individuals that died before reaching adult stage and the survival period was also evaluated. Determinations included the duration of each instar, nymphal period of surviving aphids, mortality during that period, reproductive period, daily and total offspring produced, longevity and duration of the biological cycle of $A$. gossypii aphids. The effect of neem concentrations on $A$. gossypii was also determined by means of fertility life tables, with parameters calculated according to Silveira Neto et al. (1976):

$\mathrm{R}_{0}=\sum\left(\mathrm{m}_{\mathrm{x}} \mathrm{l}_{\mathrm{x}}\right)$,

where $R_{0}$ is the net reproductive rate; $m_{x}$ is the number of females produced per female at age $\mathrm{x}$; and $\mathrm{l}_{\mathrm{x}}$ is the survival rate at age $\mathrm{x}$; and

$\mathrm{r}_{\mathrm{m}}=\left(\log _{\mathrm{e}} \mathrm{R}_{0}\right) / \mathrm{T}$,

where $\log _{e} R_{0}$ is anti-logarithmic of $R_{0}$ and $T$ is mean generation time. 


\section{Results and Discussion}

Effects of neem on nymph development and survival

A. gossypii nymphs showed a decrease in the number of molts as the neem concentrations increased (Table 1). Aphids reared on cotton leaf discs submitted to a concentration of $1,410.0 \mathrm{mg} / 100 \mathrm{~mL}$ showed on average less than one molt, while control nymphs showed 3.5 molts on average.

These results are similar to those obtained by Stark \& Rangus (1994) for Acyrthosiphon pisum (Harris) nymphs exposed to bean plants treated with Margosan-O, a commercial neem formulation. According to these authors, the molting process for this species was totally interrupted at the two highest concentrations (80 and $100 \mathrm{mg}$ azadirachtin/L) with a mean of 0.7 molts. For the aphid Toxoptera citricida (Kirkaldy), nymphs reared on citrus seedlings sprayed with Neemix at concentrations from 2.2 to $18 \mathrm{mg}$ of azadirachtin $/ 100 \mathrm{~mL}$ showed a similar behavior, undergoing 0.4 molts on average (Tang et al., 2002). Azadirachtin, the active principle of neem, causes an interruption in the concentrations of ecdisone and juvenile hormone in the hemolymph, affecting molting, metamorphosis and reproduction (Mordue \& Nisbet, 2000).

In the present study, A. gossypii nymphs exposed to higher concentrations of neem frequently died during the molting process, and parts of the old integument remained attached to the body of the insect. Another observed symptom was a change in nymph coloration from yellow to brownish black. An identical symptom was reported by Stark \& Rangus (1994) for nymphs and adults of $A$. pisum maintained on bean seedlings treated with high concentrations of Margosan-O. Azadirachtin causes a number of effects on pest insects, including growth regulation, which brings about a disruption of development and molting (Schmutterer, 1990; Mordue et al., 1998). The active principle found in neem causes severe damage in insects by interfering with molting. Larvae and nymphs are affected since they depend on this process for their development and growth. Molting could be interrupted, causing the death of the insect either during the larval or nymphal stage or during the pupal period (Martinez, 2002).

A. gossypii aphids exposed to the higher concentration of neem $(1,410.0 \mathrm{mg} / 100 \mathrm{~mL})$ showed $85.6 \%$ reduction in survival period in relation to aphids submitted to the control (Table 1). Aphids submitted to a concentration of $1,410.0 \mathrm{mg} / 100 \mathrm{~mL}$ survived only until the first instar and after this stage $100 \%$ mortality was observed. For surviving nymphs, the duration of instars and of the nymphal period were not significantly different between aphids submitted to neem treatments and control. The first, second, third and fourth instars lasted on average 1.6, 1.3, 1.3 and 1.4 days, respectively. These results are similar to those found by Xia et al. (1999) and Michelloto (2002) for this same aphid species maintained on cotton plants. The nymphal period lasted 5.5 days, a value that is close to those obtained by Akey \& Butler Junior (1989) and Kersting et al. (1999) for A. gossypii, reared on cotton cultivars Stoneville 825 and Çukurova 1518 at $25^{\circ} \mathrm{C}$, respectively.

With the exception of the highest concentration utilized, the concentrations did not extend the development stages of surviving aphids (Table 1). Neem can cause a delay in insect development (Martinez, 2002), however, its potential is affected by the rate and frequency of application (Partridge \& Borden, 1997), life stage during which the aphid is exposed, as well as by the type of exposure (Stark \& Rangus, 1994).

Table 1. Development (days) of Aphis gossypii on cotton treated with aqueous extracts of neem (Azadirachta indica) seed powder. Temperature of $25 \pm 1{ }^{\circ} \mathrm{C}$, relative humidity of $70 \pm 10 \%$ and photophase of 12 hours ${ }^{(1)}$.

\begin{tabular}{lccccccc}
\hline $\begin{array}{l}\text { Treatment }(\mathrm{mg} / 100 \mathrm{~mL} \\
\text { of water) }\end{array}$ & No. of molts & $\begin{array}{c}\text { Mean survival } \\
\text { period }\end{array}$ & & \multicolumn{3}{c}{ Instar duration } & \multicolumn{2}{c}{$\begin{array}{c}\text { Nymphal } \\
\text { period }\end{array}$} \\
\cline { 3 - 7 } & & $1^{\text {st }}$ & $2^{\text {nd }}$ & $3^{\text {rd }}$ & $4^{\text {th }}$ & & \\
Control & $3.5 \pm 0.40 \mathrm{a}$ & $17.4 \pm 2.69 \mathrm{a}$ & $1.5 \pm 0.26 \mathrm{a}$ & $1.2 \pm 0.12 \mathrm{a}$ & $1.3 \pm 0.14 \mathrm{a}$ & $1.4 \pm 0.29 \mathrm{a}$ & $5.4 \pm 0.32 \mathrm{a}$ \\
23.8 & $3.1 \pm 0.37 \mathrm{ab}$ & $14.7 \pm 3.19 \mathrm{ab}$ & $1.6 \pm 0.18 \mathrm{a}$ & $1.3 \pm 0.12 \mathrm{a}$ & $1.2 \pm 0.12 \mathrm{a}$ & $1.4 \pm 0.28 \mathrm{a}$ & $5.2 \pm 0.28 \mathrm{a}$ \\
122.0 & $2.8 \pm 0.44 \mathrm{bc}$ & $13.0 \pm 3.57 \mathrm{~b}$ & $1.6 \pm 0.26 \mathrm{a}$ & $1.2 \pm 0.18 \mathrm{a}$ & $1.3 \pm 0.28 \mathrm{a}$ & $1.4 \pm 0.14 \mathrm{a}$ & $5.4 \pm 0.53 \mathrm{a}$ \\
410.0 & $2.2 \pm 0.46 \mathrm{c}$ & $7.2 \pm 1.48 \mathrm{c}$ & $1.7 \pm 0.39 \mathrm{a}$ & $1.5 \pm 0.16 \mathrm{a}$ & $1.4 \pm 0.29 \mathrm{a}$ & $1.5 \pm 0.26 \mathrm{a}$ & $5.9 \pm 0.73 \mathrm{a}$ \\
$1,410.0^{(2)}$ & $0.6 \pm 0.25 \mathrm{~d}$ & $2.5 \pm 0.40 \mathrm{~d}$ & $1.4 \pm 0.31 \mathrm{a}$ & - & - & - & - \\
\hline Mean & 2.4 & 11.0 & 1.6 & 1.3 & 1.3 & 1.4 & 5.5 \\
CV $(\%)$ & 16.1 & 23.2 & 18.5 & 11.4 & 17.3 & 17.7 & 9.1 \\
\hline
\end{tabular}

${ }^{(1)}$ Means followed by a common letter in the column did not differ significantly at $5 \%$ probability level by Tukey test; parameters calculated considering only aphids that reached the adult stage; data are means \pm standard error. ${ }^{(2)}$ Treatment showing $100 \%$ mortality in the nymphal stage. 
The mortality of nymphs exposed to neem was dependent upon concentration and a linear relationship occurred between these variables (Figure 1). This observation is similar to the verified by Tang et al. (2002), that the mortality of nymphs and adults of T. citricida on citrus treated with Neemix was dependent upon rate, and to results by Lowery et al. (1993), who found a positive correlation between aphid mortality and neem extract rates. In the present study, the percentage mortality during the nymphal period of A. gossypii at the two highest concentrations was of $60.0 \%$ and $100.0 \%$, respectively.

\section{Effects of neem on longevity and reproduction}

The neem extracts negatively influenced A. gossypii reproduction, reducing the net reproductive rate $\left(\mathrm{R}_{0}\right)$ and the intrinsic rate of population increase $\left(\mathrm{r}_{\mathrm{m}}\right)$ of aphids exposed to neem treatments since their nymphal stage (Figures 2 and 3). The net reproductive rate $\left(\mathrm{R}_{0}\right)$, that is, the number of nymphs laid by each female during one generation, decreased as the extract concentration increased. This rate was of 35.0 nymphs for each female in the control and 0.0 nymph/female for the group of females exposed from birth to a concentration of $1,410 \mathrm{mg}$ neem seed powder/100 mL (Figure 2). The intrinsic rate of population increase $\left(r_{m}\right)$, which represents the population growth index of the aphid, also decreased as concentration increased. The highest $r_{m}$ was obtained for adults in the control (0.32), while for aphids submitted to the highest neem concentration this rate was zero (Figure 3). These results corroborate those by Stark \& Wennergren (1995) on effects of the

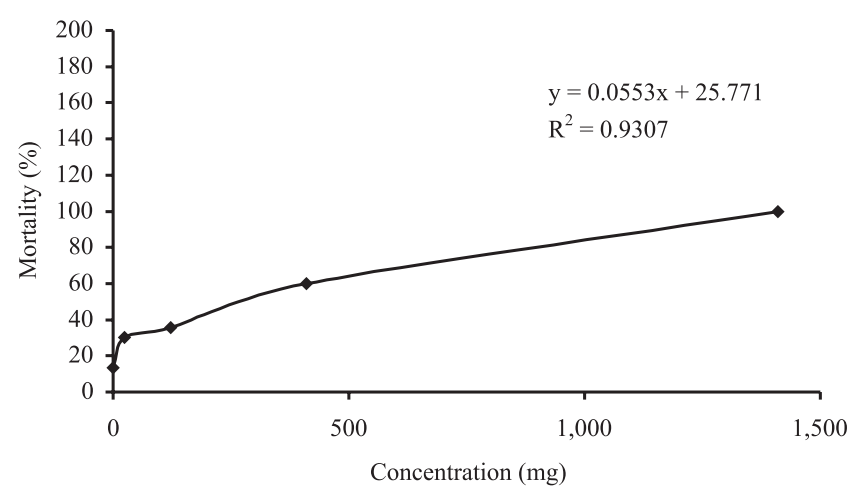

Figure 1. Percentage of mortality during the nymphal period of Aphis gossypii on cotton treated with aqueous extracts of neem (Azadirachta indica) seed powder. Temperature of $25 \pm 1^{\circ} \mathrm{C}$, relative humidity of $70 \pm 10 \%$ and photophase of 12 hours.

Pesq. agropec. bras., Brasília, v.39, n.11, p.1071-1076, nov. 2004 neem-based insecticide Margosan-O against the aphid A. pisum.

The reproductive period of surviving A. gossypii aphids, 12.9 days on average, was not significantly influenced by the concentration of neem extracts (Table 2). However, the daily and total offspring produced were lower at the higher concentrations. Adults submitted to the control treatment and to the lowest neem concentration $(23.8 \mathrm{mg} / 100 \mathrm{~mL})$ produced twice as many nymphs in relation to adults maintained on leaf discs treated with $410.0 \mathrm{mg}$ of neem extract/100 mL. Neem extracts at several concentrations reduced the fecundity of the aphids A. pisum on faba bean plants (Stark \& Rangus, 1994; Stark \& Wennergren, 1995), Myzus persicae (Sulzer) on sweet pepper, Nasonovia ribisnigri (Mosley) on lettuce, and Chaetosiphon fragaefolii (Cockerell) on strawberry (Lowery \& Isman, 1996), Elatobium abietinum (Walker) on conifers (Partridge \& Borden, 1997) and T. citricida on citrus (Tang et al., 2002).

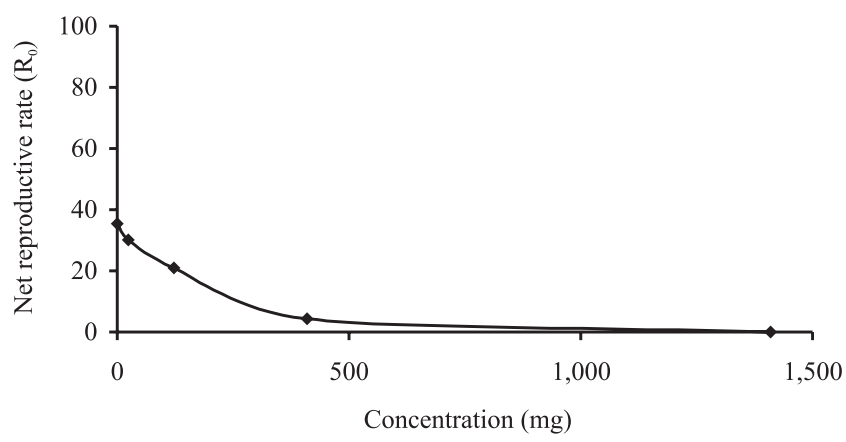

Figure 2. Net reproductive rate $\left(\mathrm{R}_{0}\right)$ of Aphis gossypii on cotton treated with aqueous extracts of neem (Azadirachta indica) seed powder. Temperature of $25 \pm 1^{\circ} \mathrm{C}$, relative humidity of $70 \pm 10 \%$ and photophase of 12 hours.

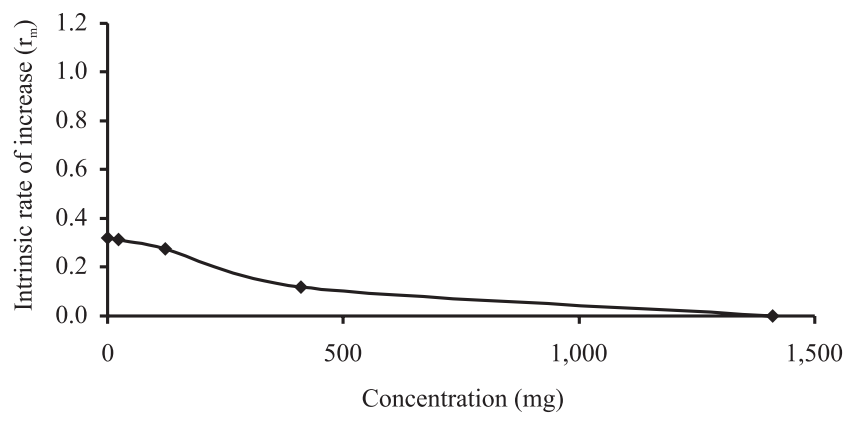

Figure 3. Intrinsic rate of population increase $\left(\mathrm{r}_{\mathrm{m}}\right)$ of Aphis gossypii on cotton treated with aqueous extracts of neem (Azadirachta indica) seed powder. Temperature of $25 \pm 1^{\circ} \mathrm{C}$, relative humidity of $70 \pm 10 \%$ and photophase of 12 hours. 
Survival A. gossypii adults had their longevity and biological cycle duration reduced as a function of the neem extract concentrations (Table 3). The control aphids showed a biological cycle with a mean duration of 20.3 days and a longevity of approximately 15.0 days, while those exposed to cotton leaves treated with a neem concentration of $410.0 \mathrm{mg} / 100 \mathrm{~mL}$ showed a cycle of approximately 15.0 days and a mean longevity of 8.8 days.

Studies on the effect of lethal and sublethal concentrations of natural insecticides on the biology of

Table 2. Reproductive period (days), daily and total offspring in surviving Aphis gossypii aphids on cotton treated with aqueous extracts of neem (Azadirachta indica) seed powder. Temperature of $25 \pm 1^{\circ} \mathrm{C}$, relative humidity of $70 \pm 10 \%$ and photophase of 12 hours $^{(1)}$.

\begin{tabular}{lccc}
\hline $\begin{array}{l}\text { Treatment } \\
(\mathrm{mg} / 100 \mathrm{~mL} \\
\text { of water) }\end{array}$ & $\begin{array}{c}\text { Reproductive } \\
\text { period }\end{array}$ & $\begin{array}{c}\text { No. of } \\
\text { offspring/day }\end{array}$ & $\begin{array}{c}\text { Total } \\
\text { number of } \\
\text { offspring }\end{array}$ \\
\hline Control & $13.1 \pm 1.71 \mathrm{a}$ & $3.6 \pm 0.50 \mathrm{a}$ & $43.0 \pm 3.24 \mathrm{ab}$ \\
23.8 & $13.2 \pm 2.96 \mathrm{a}$ & $3.6 \pm 0.50 \mathrm{a}$ & $45.6 \pm 2.81 \mathrm{a}$ \\
122.0 & $12.5 \pm 3.39 \mathrm{a}$ & $3.0 \pm 0.85 \mathrm{a}$ & $33.4 \pm 3.42 \mathrm{~b}$ \\
410.0 & $12.6 \pm 2.28 \mathrm{a}$ & $1.7 \pm 0.60 \mathrm{~b}$ & $20.3 \pm 1.43 \mathrm{c}$ \\
$1,410.0^{(2)}$ & - & - & - \\
\hline Mean & 12.9 & 2.9 & 35.6 \\
CV $(\%)$ & 20.7 & 21.4 & 19.5 \\
\hline
\end{tabular}

(1) Means followed by a common letter in the column did not differ significantly at $5 \%$ probability level by Tukey test; parameters calculated considering only aphids that reached the adult stage; data are means \pm standard error. ${ }^{(2)}$ Treatment showing $100 \%$ mortality in the nymphal stage.

Table 3. Duration (days) of biological cycle and longevity of survival Aphis gossypii aphids on cotton treated with aqueous extracts of neem (Azadirachta indica) seed powder. Temperature of $25 \pm 1^{\circ} \mathrm{C}$, relative humidity of $70 \pm 10 \%$ and photophase of 12 hours $^{(1)}$.

\begin{tabular}{lcc}
\hline $\begin{array}{l}\text { Treatment } \\
(\mathrm{mg} / 100 \mathrm{~mL} \text { of water })\end{array}$ & Biological cycle & Longevity \\
\hline Control & $20.3 \pm 1.24 \mathrm{a}$ & $15.0 \pm 1.19 \mathrm{a}$ \\
23.8 & $20.5 \pm 1.70 \mathrm{a}$ & $15.2 \pm 1.70 \mathrm{a}$ \\
122.0 & $17.0 \pm 1.06 \mathrm{ab}$ & $11.5 \pm 1.11 \mathrm{ab}$ \\
410.0 & $14.8 \pm 1.10 \mathrm{~b}$ & $8.8 \pm 1.11 \mathrm{~b}$ \\
$1,410.0^{(2)}$ & - & - \\
\hline Mean & 18.1 & 12.6 \\
$\mathrm{CV}(\%)$ & 17.5 & 25.2 \\
\hline${ }^{(1)}$ Means followed by a common letter in the column did not differ \\
significantly at 5\% probability level by Tukey test; parameters calculated \\
considering only aphids that reached the adult stage; data are \\
means \pm standard error. ${ }^{(2)}$ Treatment showing 100\% mortality in the \\
nymphal stage.
\end{tabular}

pest insects are quite important. In spite of the fact that high concentrations of neem can cause high mortality in aphids, these are possibly not economically viable. Intermediate concentrations have been recommended, since they can be utilized in association with other methods, such as biological control (Tang et al., 2002). Since the cotton aphid presents a great diversity of natural enemies, the evaluated concentrations provide basic knowledge for future studies on the association between natural insecticides and biological control.

Neem-based insecticides efficiently control several aphid species in the field (Lowery et al., 1993). In the laboratory, the aqueous extract of neem seeds was efficient against the aphid A. gossypii, causing nymph mortality and reducing their survival period and fecundity. Since the potential of this natural insecticide varies according to meteorological conditions (Partridge \& Borden, 1997), additional studies are necessary to evaluate its efficiency under field conditions.

\section{Conclusion}

1. The neem extracts negatively influence A. gossypii reproduction, reducing the net reproductive rate $\left(\mathrm{R}_{0}\right)$ and the intrinsic rate of population increase $\left(r_{m}\right)$ of aphids exposed to neem treatments since their nymphal stage.

2. The aqueous extract of neem seeds is efficient against the aphid $A$. gossypii, causing nymph mortality and reducing their survival period and fecundity.

\section{Acknowledgements}

To Fapesp (Fundação de Amparo à Pesquisa do Estado de São Paulo) and CNPq (Conselho Nacional de Desenvolvimento Científico e Tecnológico), for the scholarships to the authors.

\section{References}

\begin{abstract}
AHMED, S.; GRAINGE, M. Potential of the neem tree (Azadirachta indica) for pest control and rural development. Economy Botany, v.40, p.201-209, 1986.
\end{abstract}

AKEY, D.H.; BUTLER JUNIOR, G.D. Developmental rates and fecundity of apterous Aphis gossypii on seedlings of Gossypium hirsutum. Southwestern Entomologist, v.14, p.295-299, 1989.

CHITRA, K.C.; RAO, S.J.; RAO, P.K. Efficacy of plant extracts for controlling cotton aphid (Aphis gossypii). Indian Journal of Agricultural Sciences, v.67, p.134-135, 1997. 
FREEMAN, B.L.; SMITH, R.H. Cotton aphids. Alabama Cooperative Extension System, Alabama A\&M and Auburn Universities. Disponível em <http://www.aces.edu/department/extcomn/publication/anr/anr-845/pdf/anr-845.pdf> Acesso em: 15 nov. 2002.

GODFREY, L.D.; FUSON, K.J. Environmental and host plant effects on insecticide susceptibility of the cotton aphid (Homoptera: Aphididae). Journal of Cotton Science, v.5, p.22-29, 2001.

GODFREY, L.D.; ROSENHEIM, J.A.; GOODELL, P. Cotton aphid emerges as major pests in SJV cotton. California Agriculture, v.54, p.26-29, 2000.

HENEBERRY, T.J.; JECH, L.F. Cotton aphid biology and honeydew production. University of Arizona, College of Agriculture and Life Sciences, 2001. Arizona Cotton Report. Disponível em: < http:/ /ag.arizona.edu/pubs/crops/az1221/> Acesso em: 30 nov. 2002.

IMMARAJU, J.A. The commercial use of azadirachtin and its integration into viable pest control programmes. Pesticide Science, v.54, p.285-289, 1998.

KABISSA, J.C.B.; KAYUMBO, H.Y.; YARRO, J.G. Seasonal abundance of chrysopids (Neuroptera: Chrysopidae) preying Helicoverpa armigera (Hubner) (Lepidoptera: Noctuidae) and Aphis gossypii (Glover) (Homoptera: Aphididae) on cotton in eastern Tanzania. Crop Protection, v.15, p.5-8, 1996.

KERSTING, U.; SATAR, S.; UYGUN, N. Effect of temperature on development rate and fecundity of apterous Aphis gossypii Glover (Hom., Aphididae) reared on Gossypium hirsutum L. Journal of Applied Entomology, v.123, p.23-27, 1999.

LOWERY, D.T.; ISMAN, M.B. Inhibition of aphid (Homoptera: Aphididae) reproduction by neem seed oil and azadirachtin. Journal of Economic Entomology, v.89, p.602-607, 1996.

LOWERY, D.T.; ISMAN, M.B.; BRARD, N.L. Laboratory and field evaluation of neem for the control of aphids (Homoptera: Aphididae). Journal of Economic Entomology, v.86, p.864-870, 1993.

MANN, G.S.; DHALIWAL, G.S.; DHAWAN, A.K. Field efficacy of neem based insecticides against whitefly and their impact on insect pest complex of cotton. Pesticide Research Journal, v.13, p.79-81, 2001.

MARTINEZ, S. Ação do nim sobre os insetos. In: MARTINEZ, S.S. (Ed.). O nim - Azadirachta indica: natureza, usos múltiplos, produção. Londrina: Iapar, 2002. p.59-64.

MICHELLOTO, M.D. Aspectos bioecológicos de Aphis gossypii Glover, 1877 (Hemiptera: Aphididae) e diversidade de afídeos na cultura do algodão. 2002. 72p. Dissertação (Mestrado) Universidade Estadual Paulista, Jaboticabal.

MORDUE, A.J.; NISBET, A.J. Azadirachtin from the neem tree Azadirachta indica: its actions against insects. Anais da Sociedade Entomológica do Brasil, v.29, p.615-632, 2000.

MORDUE, A.J.; SIMMONDS, S.V.L.; BLANEY, W.M.; NASIRUDIN, M.; NISBET, A.J. Actions of azadirachtin, a plant allelochemical, against insects. Pesticide Science, v.54, p.277-284, 1998.

PARTRIDGE, M.; BORDEN, J.H. Evaluation of neem seed extract for control of the spruce aphid, Elatobium abietinum (Walker) (Homoptera: Aphidae). Canadian Entomologist, v.129, p.899-906, 1997.

SCHMUTTERER, H. Properties and potential of natural pesticides from the neem tree, Azadirachta indica. Annual Review of Entomology, v.35, p.271-297, 1990.

SILVEIRA NETO, S.; NAKANO, O.; BARBIN, D.; VILLA NOVA, N. Manual de ecologia dos insetos. São Paulo: Ceres, 1976. p.60253.

STARK, J.D.; RANGUS, T.M. Lethal and sublethal effects of the neem insecticide formulation, 'Margosan-O', on the pea aphid. Pesticide Science, v.41, p.155-160, 1994.

STARK, J.D.; WENNERGREN, U. Can population effects of pesticides be predicted from demographic toxicological studies? Journal of Economic Entomology, v.88, p.1089-1096, 1995.

TANG, Y.Q.; WEATHERSBEE III, A.A.; MAYER, R.T. Effect of neem extract on the brown citrus aphid (Homoptera: Aphididae) and its parasitoid Lysiphlebus testaceipes (Hymenoptera: Aphididae). Environmental Entomology, v.31, p.172-176, 2002.

ULRICHS, C.H.; MEWIS, I.; SCHNITZLER, W.H. Efficacy of neem and diatomaceous earth against cowpea aphids and their deleterious effect on predating Coccinelidae. Journal of Applied Entomology, v.125, p.571-575, 2001.

WEATHERSBEE III, A.A.; HARDEE, D.D.; MEREDITH JUNIOR, W.R. Differences in yield response to cotton aphids (Homoptera: Aphididae) between smooth leaf and hairy-leaf isogenic cotton lines. Journal of Economic Entomolgy, v.88, p.749-754, 1995.

XIA, J.Y.; WERF, W. van der; RABBINGE, R. Influence of temperature on bionomics of cotton aphid, Aphis gossypii, on cotton. Entomologia Experimentalis et Applicata, v.90, p.25-35, 1999.

Received on September 9, 2003 and accepted on September 8, 2004

Pesq. agropec. bras., Brasília, v.39, n.11, p.1071-1076, nov. 2004 